\title{
CD9 Plays a Role in Schwann Cell Migration in vitro
}

\author{
Eva S. Anton, ${ }^{1}$ Michael Hadjiargyrou, ${ }^{2}$ Paul H. Patterson, ${ }^{2}$ and William D. Matthew ${ }^{1}$ \\ 'Department of Neurobiology, Duke University Medical Center, Durham, North Carolina 27710 and ${ }^{2}$ Division of Biology, \\ California Institute of Technology, Pasadena, California 91125
}

\begin{abstract}
To identify molecules that regulate Schwann cell migration, we have generated a panel of monoclonal antibodies against Schwann cell surface antigens that modulate Schwann cell migration in in vitro bioassays. One of these antibodies, SMRA1, recognizes a $26 \mathrm{kDa}$ Schwann cell surface membrane protein identified here as CD9. SMRA1 enhances Schwann cell migration on two biologically relevant substrates: living axons of cultured dorsal root ganglion neurons, and cryostat sections of sciatic nerve. This CD9-induced regulation of Schwann cell motility is correlated with a rise in cytosolic calcium and enhanced tyrosine phosphorylation of several Schwann cell proteins. These results, together with the findings of Hadjiargyrou and Patterson (1994), implicate CD9 as an important regulator of Schwann cell behavior in peripheral nerve.
\end{abstract}

[Key words: Schwann cells, CD9, migration, calcium, tyrosine phosphorylation, antibodies]

Schwann cells migrate extensively during the development and regeneration of peripheral nerves. To populate the PNS during development, Schwann cells first migrate along axons at the outer surface of the developing nerve and then migrate perpendicular to the nerve axis into the axon bundles (Peters and Muir, 1959; Cravioto, 1965; Billings-Gagliardi et al., 1974; ZiskindConhaim, 1988). Migrating Schwann cells may also play a role in axon growth and guidance during development (Keynes, 1987; Noakes and Bennett, 1987; Noakes et al., 1988). Schwann cell migration is also a crucial and often limiting factor in recovery from PNS injuries and neuropathies (Williams et al., 1983; Hall, 1986a,b; Griffin et al., 1987; Fields et al., 1989; Fenely et al., 1991; Guernard et al., 1992; Franklin and Blakemore, 1993).

Schwann cell migration in vivo can occur on two substrates: axonal surfaces and extracellular matrix components. Thus, there are a number of candidate molecules that might regulate Schwann cell migration. During development and regeneration, migrating Schwann cells express elevated levels of adhesion molecules (Nicke and Schachner, 1985; Daniloff et al., 1986; Daston and Ratner, 1991), extracellular matrix molecules and their receptors (Engvall et al., 1990; Sanes et al., 1990; Lefcort et al., 1992; Sirronen et al., 1992; Jaakola et al., 1993), trophic factors and

\footnotetext{
Received Mar. 29, 1994; revised June 13, 1994; accepted July 12, 1994.

Expert technical assistance was provided by Daryl Jones and Susan Ou. Support was provided by NSF Grant 9006752 and NIH Grant NS02253 to W.D.M., NIH Grant NS30216 to P.H.P., and by an American Heart Association fellowship to M.H.

Correspondence should be addressed to William D. Matthew, Duke University Medical Center, Department of Neurobiology, Box 3209, Durham, NC 27710.

Copyright (C) 1995 Society for Neuroscience $0270-6474 / 95 / 150584-12 \$ 05.00 / 0$
}

their receptors (Heumann et al., 1987; Taniuchi et al., 1987; Kanje et al., 1989; Acheson et al., 1991; Toma et al., 1992); proteases (Meier et al., 1989; Kiousssi et al., 1992), and the growth and motility regulating protein GAP-43 (Curtis et al., 1992). Of these molecules, NGF, p75 NGF receptor, merosin, laminin, fibronectin, and $\mathrm{N}$-cadherin have been shown to regulate Schwann cell migration (Baron-Van Evercooren et al., 1982; McCarthy et al., 1983; Longo et al., 1984; Le Beau et al., 1988; Letourneau et al., 1991; Bailey et al., 1993; Anton et al., $1994 a, b)$. Thus, the temporal correlation between migration and elevated Schwann cell expression of various cell surface and extracellular matrix molecules is a useful indicator of which molecules may modulate Schwann cell migration. This indicator will, however, neither identify novel functional molecules nor implicate other known molecules not yet found in Schwann cells. To identify such functionally relevant molecules, we generated a panel of monoclonal antibodies (mAb) that modulate Schwann cell migration in two in vitro bioassays. These mAbs are referred to by the prefix SMRA, for Schwann cell migration regulating antibodies.

To generate mAbs against antigens that specifically modulate Schwann cell migration, mice were first tolerized to a homogenate of fibroblasts using the immunosuppressant drug cyclophosphamide (Matthew and Sandrock, 1987), and then immunized with a Schwann cell homogenate. One of the mAb, SMRA1, from this fusion dramatically facilitates Schwann cell migration in vitro. SMRA1 was found to recognize a $26 \mathrm{kDa}$ Schwann cell surface glycoprotein known as CD9.

In the nervous system, CD9 is found on embryonic sensory, sympathelic, and motor neurons, adrenal chromaffin cells, PNS and CNS glial cells, retina, and on certain retinoblastoma and neuroblastoma cell lines (Boucheix and Benoit, 1988; MartinAlonso et al., 1992; Tole and Patterson, 1993). It is present on rat Schwann cells as early as embryonic day 17 . Recent studies on molecules that define positional information in the PNS have identified a putative epitope on CD9 that is expressed preferentially by Schwann cells in rostral rather than caudal nerves and ganglia (Suzue et al., 1990; Kaprielian and Patterson, 1993). CD9 is also a major cell surface protein in various hematopoetic cells, including pre-B cells, platelets, and activated T lymphocytes (Jennings et al., 1990; Masellis-Smith et al., 1990). In pre-B cells and platelets, CD9 regulates cell activation and aggregation, possibly through an association with an integrin (Slupsky et al., 1989). In the process, mAbs to CD9 induce tyrosine phosphorylation and increases in intracellular calcium concentration in platelets (Boucheix et al., 1987; Favier et al., 1990; Seehafer and Shaw, 1991; Kroll et al., 1992; Yatomi et al., 1993). mAbs to CD9 also enhance neutrophil adhesion to endothelial cells (Forsyth, 1991). Furthermore, CD9 regulates cell motility in a 
variety of cell lines (Ikeyama et al., 1993). CD9 could therefore regulate cell adhesion and cell motility in Schwann cells.

We report here that a $\mathrm{mAb}$ against CD9, SMRA1, stimulates Schwann cell migration on cryostat nerve sections and on living axons. SMRAl also induces an increase in intracellular calcium levels and in the tyrosine phosphorylation of several Schwann cell proteins. Such functional effects of CD9, as well as the differential expression of a putative CD9 epitope on Schwann cells, suggest that CD9 is an important regulator of Schwann cell behavior in the PNS.

\section{Materials and Methods}

\section{Monoclonal antibodies to $C D 9$}

Antibody SMRAl is one of the panel of mAbs raised against Schwann cell antigens using the previously described cyclophosphamide immunosuppression paradigm (Matthew and Sandrock, 1987). A BALB/c mouse was tolerized with an injection of $15 \mathrm{mg}$ of protein from whole cell extracts of the rat 3T3 fibroblast cell line. Over the next $48 \mathrm{hr}$, three injections of cyclophosphamide were administered at $100 \mathrm{mg} / \mathrm{kg}$ dosage at $14 \mathrm{hr}$ intervals. The animal was tolerized with the same antigens and cyclophosphamide again at 14,42 , and $70 \mathrm{~d}$. Two weeks after the second tolerization procedure (day 28), the animal was immunized with $20 \mathrm{mg}$ of protein from whole cell extracts of the mouse B1.1 Schwann cell line. The B1.1 cell line was generated by immortalizing primary mouse Schwann cells from neonatal sciatic nerve with a transforming retrovirus (B. Yankner and W. D. Matthew, unpublished observations). The immunization procedure was repeated again at 56 and $84 \mathrm{~d}$. Three days after the final immunization (day 87), the mouse was sacrificed and hybridomas were made from its spleen as described by Matthew and Sandrock (1987). Hybridomas grown in RPMI $/ 10 \%$ fetal calf serum media were subcloned repeatedly. SMRA1 is a mAb of the IgM isotype. mAbs ROCA1, ROCA2, and B2C11 have been previously described as specific to rat CD9 (Akeson and Warren, 1984; Kaprielian and Patterson, 1993; Kaprielian et al., 1994) and are of the IgG isotype.

\section{Immunoprecipitation, electrophoresis, and immunoblotting}

Triton X-100-soluble fractions of adult rat sciatic nerve membranes or S-16 Schwann cell membranes (Goda et al., 1991) were prepared and CD9 was immunoprecipitated from these extracts, using a protein Gsepharose column and the SMRA1 mAb, as described by Kaprielian and Patterson (1993). An anti-mouse IgM mAb of the IgG isotype (Boehringer-Mannheim) was used to bind the SMRA1-CD9 complex to the protein G-sepharose column. Pure CD9 is a gift from Dr. Z. Kaprielian. Platelet extracts were prepared as described by Boucheix et al. (1983).

One-dimensional SDS-polyacrylamide gel electrophoresis (SDSPAGE) was performed according to the method of Laemmli (1970) on $10 \%$ polyacrylamide gels. All samples were run under nonreducing conditions. Following transfer to nitrocellulose $(0.45 \mu \mathrm{m}$, Bio-Rad), protein bands were detected by immunoblotting. The transfer was performed overnight using a Bio-Rad minigel transfer apparatus; the blots were then blocked for $30 \mathrm{~min}$ in Tris-buffered saline (TBS; $0.9 \% \mathrm{NaCl}, 20$ mM Tris- $\mathrm{HCl}, \mathrm{pH} 7.4)$ containing $5 \%$ nonfat dry milk (Carnation) at room temperature. The blocked nitrocellulose was incubated for $3 \mathrm{hr}$ at room temperature with hybridoma supernatants from one of the following mAbs: ROCA1, ROCA2, B2C11, and SMRA1. After three $15 \mathrm{~min}$ washes in TBS $/ 0.5 \%$ Tween-20 (TBST), blots were incubated for $1 \mathrm{hr}$ with 1:100 biotinylated goat anti-mouse IgG or IgM (Vector) in blocking solution. Blots were then washed three times in TBST and incubated for $45 \mathrm{~min}$ with avidin-biotinylated horseradish peroxidase solution (ABC kit, Vector). After the final incubation, blots were washed twice in TBST and once in TBS prior to detection of bound antibodies with $0.05 \%$ diaminobenzidine (DAB) in $0.03 \%$ hydrogen peroxide. The reaction was stopped after $15 \mathrm{~min}$ by transferring the blots to distilled water.

\section{Immunohistochemistry}

Primary Schwann cells from one day rat sciatic nerve were dissociated and cultured in RPMI $/ 10 \%$ FCS medium as described by Brockes et al. (1979). After $2 \mathrm{~d}$ in culture, cells were incubated live in hybridoma supernatant for $1 \mathrm{hr}$ at room temperature. After three $5 \mathrm{~min}$ rinses in
$\mathrm{RPMI} / 10 \% \mathrm{FCS}$ at room temperature, the cells were incubated in fluorescein-conjugated goat antiserum to mouse immunoglobulins (1:50 dilution in RPMI/10\% rat serum; Antibodies Inc.) for $45 \mathrm{~min}$ at room temperature. Following three 5 min rinses in RPMI/10\% FCS at room temperature, cells were mounted in the same medium for observation in a Zeiss epifluorescence microscope.

In some experiments, fresh-frozen $15 \mu \mathrm{m}$ cryostat sections of normal or denervated sciatic nerves collected on gelatin-coated slides were stained with SMRA1.

\section{Bioassays for Schwann cell migration}

In vitro bioassay to study Schwann cell migration on cryostat tissue sections. Thoracic level, dorsal root ganglia (DRG) were removed from l d Sprague-Dawley (Charles River) rat pups and placed in ice-cold RPMI medium (GIBCO) supplemented with $10 \%$ fetal calf serum (FCS, Hyclone). After dissecting away blood vessels and nerve rootlets, ganglia were treated with $0.03 \%$ collagenase (Sigma) and $0.25 \%$ trypsin (Sigma) in RPMI medium for $30 \mathrm{~min}$ at $37^{\circ} \mathrm{C}$. Subsequently, DRGs were incubated with $0.01 \%$ DNase (Sigma) and $0.25 \%$ anti-trypsin (Sigma) in $\mathrm{RPMI} / 10 \% \mathrm{FCS}$ medium for $15 \mathrm{~min}$ at $37^{\circ} \mathrm{C}$. After two rinses in RPMI/ $10 \%$ FCS medium, DRGs were explanted onto $22 \mu \mathrm{m}$ longitudinal cryostat sections of normal or denervated sciatic nerves (the latter are distal stumps of sciatic nerves transected in vivo $7 \mathrm{~d}$ prior to use). Explants were cultured for $72 \mathrm{hr}$ in a 50:50 mixture of RPMI/10\% FCS medium and hybridoma supernatant. Schwann cells migrating out of the DRG explant onto nerve substrates were then visualized by incubating the cultures with $10 \mathrm{~mm} 5,6$-carboxyfluorescein diacetate succinimidyl ester (Molecular Probes Inc.) in TBS for $5 \mathrm{~min}$ at room temperature. Cultures were immediately examined in a Zeiss microscope equipped with an epifluorescence filter. Images of these cultures were collected onto an optical disk drive and the extent of Schwann cell migration was measured using the IMAGE 1 program (Universal Imaging Inc.). A rectangular grid divided into several $100 \mu \mathrm{m}^{2}$ squares was pasted on to each of these images, and the shortest distance between the edges of the DRG and the leading Schwann cells was measured. An average of these measurements indicates the mean maximum distance Schwann cells have migrated on a particular substrate from a particular DRG explant. Measurements from different experimental groups were statistically analyzed for differences using Student's $t$ test (confidence interval $=95 \%$ or higher).

In a number of experiments, pieces of sciatic nerve from neonatal day 1 rats, instead of DRGs, provided the source of migrating Schwann cells. Sciatic nerves were removed from rat pups, cut into $\sim 1 \mathrm{~mm}$ pieces using a micro dissecting scissors, and cultured for $48 \mathrm{hr}$ on tissue culture plastic in RPMI $/ 10 \%$ FCS medium to facilitate the emigration of most of the fibroblasts from the nerve explants (Morrisey et al., 1991). Following this initial incubation, nerve explants were harvested and explanted onto appropriate nerve substrates as described above.

After carboxyfluorescein imaging, some coverslips were washed several times in PBS and stained with antibodies to S100 (a Schwann cellspecific marker, Dako Corp.) or neurofilament (Sigma). Cultures were also counterstained with $10 \mu \mathrm{M}$ bisbenzamide (Sigma) to stain nuclei.

In vitro bioassay to study Schwann cell migration on axonal surfaces. Sciatic nerves of adult, Sprague-Dawley rats were crushed in vivo two days prior to the removal of corresponding DRGs at levels L4, L5, and L6. Following removal, DRGs were incubated at $37^{\circ} \mathrm{C}$ in RPMI/N2 media (RPMI $+0.5 \mathrm{mg} / \mathrm{ml}$ insulin, $10 \mathrm{mg} / \mathrm{ml}$ transferin, $0.63 \mu \mathrm{g} / \mathrm{ml}$ progesterone, $1.611 \mathrm{mg} / \mathrm{ml}$ putrescene, and $0.52 \mathrm{mg} / \mathrm{ml}$ sodium selenite) containing $0.25 \%$ collagenase type II (Sigma) for $1.5 \mathrm{hr}$. At the end of this incubation, DRGs were triturated (16 passages) with a fire-polished glass pipette and $0.025 \%$ trypsin was added to the cell suspension. After $15 \mathrm{~min}$ at room temperature, $80 \mu \mathrm{g} / \mathrm{ml}$ DNase, and $100 \mu \mathrm{g} / \mathrm{ml}$ soybean trypsin inhibitor were added to the suspension. Following one round of gentle trituration to break up the DRGs into small neuron-Schwann cell clumps, cells were suspended in $15 \mathrm{ml}$ of RPMI $10 \%$ FCS media and centrifuged for $10 \mathrm{~min}$ at $500 \times \mathrm{g}$. The cell pellet was resuspended in RPMI $/ 10 \%$ FCS and plated on laminin $(10 \mu \mathrm{g} / \mathrm{ml})$-coated $35 \mathrm{~mm}$ petri dishes (Falcon) at a density of 500 cells/dish. After $24 \mathrm{hr}$ in culture, cells were placed onto a $37^{\circ} \mathrm{C}$ stage on a Hoffman modulation contrast optics microscope, and time-lapse recordings of Schwann cells migrating on neurites were made using video microscopy. After monitoring the baseline activity for $30 \mathrm{~min}$, media with $\mathrm{mAbs}(5 \mu \mathrm{g} / \mathrm{ml})$ were perfused into the culture and the effects of mAbs on Schwann cell migration rates, as well as the morphology of migrating Schwann cells and neurites, were 


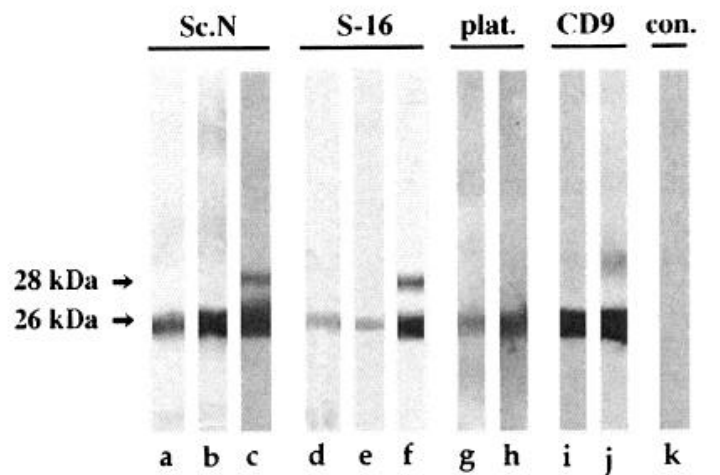

Figure 1. SMRA1 mAb recognizes CD9. Triton X-100-soluble fractions of membranes from adult sciatic nerve $(a-c)$, S-16 Schwann cells $(d-f)$, platelets $(g, h)$, and immunoaffinity purified CD9 $(i, j)$ were blotted with SMRA1 $(a, d, g, i), \operatorname{ROCA} 1(b, e, h), \operatorname{ROCA} 2(c), \operatorname{B} 2 \mathrm{C} 11(f, j)$. All of these antibodies recognize the same $26 \mathrm{kDa} C D 9$ protein. ROCA2 and $\mathrm{B} 2 \mathrm{C} 11$ also recognizes a $28 \mathrm{kDa}$ band that is a glycosylated form of CD9 molecule. SMRA1 does not recognize any proteins in the Triton $\mathrm{X}-100$-insoluble membrane/cytoskeletal fraction of the adult sciatic nerve (con., k). Approximately $100 \mu \mathrm{g}$ of protein was loaded in each lane.

monitored for $1 \mathrm{hr}$. At the end of the time-lapse recordings, cultures were fixed and stained with $\mathrm{S} 100$ antibody (a Schwann cell marker) to verify that the monitored cells were Schwann cells.

In some of the experiments, mAbs were added to the cultures at 24 $\mathrm{hr}$ and cultures maintained for another $24 \mathrm{hr}$ before staining with 5,6carboxyfluorescein diacetate succinimidyl ester and bisbenzamide. Images of such cultures were used to analyze the extent of neuron-Schwann cell association with and without $\mathrm{mAbs}$. Carboxyfluorescein labels all living cells and their processes. Bisbenzamide, used to stain the cell nuclei, avoids the identification of the large neuritic varicosities as migrating cells.

Tyrosine phosphorylation assay. Dissociated Schwann cells, prepared from neonatal rat sciatic nerve as described above, were cultured at a density of 50,000 cells/well for $48 \mathrm{hr}$ in 24 well culture dishes. The cells in each well were then incubated for $45 \mathrm{~min}$ with approximately $2 \mu \mathrm{g}$ of SMRA1 or SMRA5 (control mAb). Some of the wells were left untreated in RPMI $10 \%$ FCS medium. The cells were then rinsed twice in RPMI medium and harvested in $100 \mu$ l of boiling SDS-PAGE sample buffer ( $20 \%$ glycerol, $4 \%$ SDS, $0.125 \mathrm{M}$ Tris, $0.01 \mathrm{mg} / \mathrm{ml}$ bromophenol blue, $10 \% 2$-mercaptoethanol, $\mathrm{pH} 6.8$ ) containing $0.5 \mathrm{~mm}$ vanadate. Twenty-five microliter samples were then loaded into each well of a $10 \%$ polyacrylamide, Bio-Rad minigel and run at $200 \mathrm{mV}$. Separated proteins were blotted onto nitrocellulose, blocked first with $4 \%$ calf serum containing $0.5 \mathrm{~mm}$ vanadate and then with $10 \%$ calf serum in TBS ( $\mathrm{pH} \mathrm{7.4)} \mathrm{overnight} \mathrm{at} 4^{\circ} \mathrm{C}$. Bands of protein containing phosphorylated tyrosine were identified using an anti-phosphotyrosine $\mathrm{mAb}$ (P3300; Sigma) or a rabbit polyclonal antiserum (AB1600, Chemicon) diluted $1: 750$ in $10 \%$ calf serum. As stated by the manufacturers, these antibodies react specifically with phosphotyrosine-containing molecules. Positive bands were visualized with an anti-mouse Vectastain ABC-HRP kit using diaminobenzidine (DAB) as a substrate for peroxidase. In some experiments, labeled protein bands were visualized with an enhanced chemiluminescence (ECL, Amersham) kit using luminol as the substrate for peroxidase.

Calcium imaging. Fluo-3 AM, a membrane-permeant calcium indicator that increases in fluorescence with increasing calcium concentrations, was used to monitor calcium changes induced in Schwann cells by SMRA1. Primary cultures of Schwann cells in a $35 \mathrm{~mm}$ petri dish were incubated with $2 \mathrm{ml}$ of Opti-MEM medium (GIBCO) containing $10 \mu \mathrm{M}$ Fluo-3 acetoxymethyl ester (AM) (Molecular Probes Inc.) and the nonionic detergent pluronic acid F127 at $0.5 \mathrm{mg} / \mathrm{ml}$. Heavy metals that might bind to Fluo-3 and interfere with its calcium sensitivity were chelated by adding $10 \mathrm{M}$ Tetrakis (2-pyridyl methyl) ethylenediamine (TPEN) to the incubation medium. After an hour of incubation at $37^{\circ} \mathrm{C}$, Fluo-3-loaded cells were washed twice in Opti-MEM and placed onto a $37^{\circ} \mathrm{C}$ stage on a Zeiss microscope. Images of Fluo-3-labeled cells were collected every $1.25 \mathrm{~min}$ using the IMAGE 1 system, an SIT camera, a computer-controlled shutter on the UV light source, and an optical

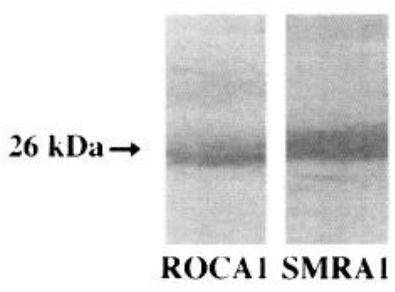

Figure 2. SMRA1 and ROCA1 bind the same $26 \mathrm{kDa}$ protein. Proteins were immunoprecipitated from Triton X-100-soluble adult sciatic nerve fractions with SMRA1 and Western blotted with ROCA1 or SMRA1 ROCA1 recognized a $26 \mathrm{kDa}$ protein band in the SMRAl immunoprecipitate (left lane). The same protein band was also recognized by SMRA1 (right lane).

image recorder. After 10-15 min of baseline recording, medium with $\mathrm{mAbs}(5 \mu \mathrm{g} / \mathrm{ml})$ was perfused onto the culture and the fluorescence changes induced in cell somas (and processes, when possible) were monitored. Fluorescence changes induced by mAbs in the cell body area was calculated as $\Delta F / F$ [(fluorescence with antibody - fluorescence baseline)/fluorescence baseline].

\section{Results}

Generation of mAbs to Schwann cell surface antigens

Antibodies to Schwann cell antigens were generated using the cyclophosphamide immunosuppression paradigm described previously (Matthew and Sandrock, 1987). Cyclophosphamide was used to suppress the immune response of mice to a 3T3 fibroblast homogenate; subsequently, animals were immunized with a B1.1 Schwann cell homogenate. Our goal was to generate $\mathrm{mAbs}$ to Schwann cell surface antigens that are involved in cell migration. Since fibroblasts are known to migrate in peripheral nerve and are known to use ubiquitous molecules such as fibronectin for their migration, we hypothesized that tolerization with fibroblast antigens followed by immunization with Schwann cell antigens would bias the immune response in the desired direction, in this case, functionally relevant and possibly novel Schwann cell specific antigens. Antibodies were first screened immunohistochemically for their ability to recognize Schwann cell surface membranes on primary, rat Schwann cells and sciatic nerve sections. Positive mAbs were then screened for their effects on in vitro Schwann cell migration bioassays. One of the mAbs resulting from this fusion, SMRA1, was found to label Schwann cell membranes strongly and to enhance the rate of Schwann cell migration in in vitro bioassays, thus implicating the SMRA1 antigen as an important regulator of Schwann cell migration.

\section{Characterization of the SMRAI antigen as CD9}

Triton X-100-soluble fractions of membrane fractions from B1.1 or S-16 Schwann cell lines and adult sciatic nerve homogenates yielded strong SMRA1 binding signals in dot blots, whereas no signal was detectable in the detergent insoluble fractions, suggesting that the SMRA1 antigen is likely to be an integral membrane protein rather than a cytoskeletal or extracellular matrix molecule. The SMRA1 antibody also bound strongly to purified CD9 in dot blots (data not shown). In an effort to identify the SMRA1 antigen unambiguously, detergentsoluble membrane fractions from adult sciatic nerves or S-16 Schwann cells were immunoblotted with SMRA1 mAb (Fig. $1 a, d)$. SMRA1 labels a $26 \mathrm{kDa}$ band, identical in molecular weight to $\mathrm{CD} 9$. The same $26 \mathrm{kDa}$ band is also labeled by three previously characterized CD 9 mAbs, ROCA1 (Fig. $1 b, e$ ), ROCA2 

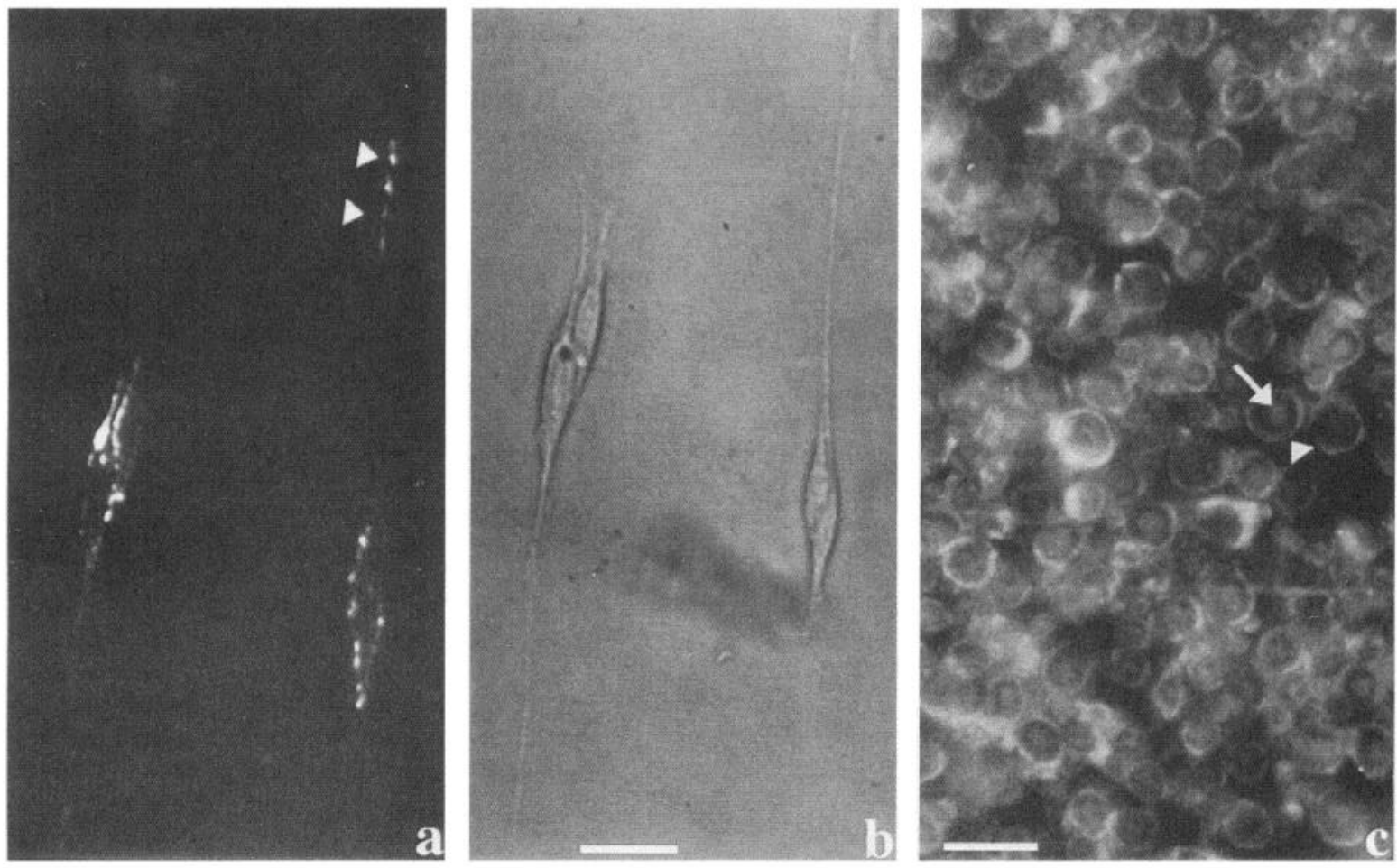

Figure 3. Immunohistochemical labeling of SMRA1 in primary rat Schwann cells and adult sciatic nerve sections. Living Schwann cells or cryostat sections of sciatic nerve were labeled with SMRA1 as described in Materials and Methods. SMRA1 labeled membranes in the cell soma and leading edges (arrowheads) of the bipolar processes $(a, b)$. In nerve section, the outer Schwann cell membrane (arrowhead, $c$ ) and axoplasm (arrow, $c$ ) were stained. Scale bars: $a$ and $b, 20 \mu \mathrm{m} ; c, 15 \mu \mathrm{m}$.

(Fig. 1c), and B2C11 (Fig. 1f). In membrane extracts of platelets, a rich source of CD9, ROCA1 and SMRA1 recognize the identical $26 \mathrm{kDa}$ band (Fig. $1 \mathrm{~g}, h$ ). SMRA1 and $\mathrm{B} 2 \mathrm{C} 11$ also recognize the identical $26 \mathrm{kDa}$ band in immunoblots of pure CD9 (Fig. $1 i, j)$. As in dot blots, SMRA1 does not bind any protein bands in the immunoblots of Triton X-100-insoluble fractions from adult sciatic nerve (con., Fig. $1 k$ ).

In addition, when the SMRA1 antigen was immunoprecipitated with the SMRA1 mAb and immunoblotted with the ROCA $1 \mathrm{mAb}$, the $26 \mathrm{kDa}$ protein is positively stained by ROCA 1 (Fig. 2). Thus, both ROCA1 and SMRA1 recognize the same $26 \mathrm{kDa}$ CD9 protein. Neither the antibodies to Schwann cell surface integrins nor anti-mouse immunoglobulins immunoprecipitated CD9.

\section{Immunohistochemical localization of the SMRAI antigen}

In living, primary rat Schwann cells, surface membrane staining is observed with SMRA1 mAb. Prominent labeling is observed on the cell soma region (Fig. $3 a$ ). The leading edges of the Schwann cell bipolar processes also label (arrowheads, Fig. $3 a$ ). When a freshly harvested cell pellet of S-16 Schwann cells was frozen, sectioned, and stained with SMRA1, labeling is seen only on the cell surface, not in the cytoplasm (data not shown). In fresh frozen, adult rat sciatic nerve sections, SMRA1 labels both the outer Schwann cell membranes (Fig. 3c, arrowhead), and the axoplasm (Fig. $3 c$, arrow). Occasionally, abaxonal Schwann cell surface membrane or axonal surface membrane staining is observed. No specific staining is observed in the Schwann cell cytoplasm or in the myelin layers. We were unable to determine if endoneurial fibroblasts labeled with SMRA1 in nerve sections. Treatment with secondary antibodies alone did not label primary Schwann cells or nerve sections.

\section{The SMRAI antibody promotes Schwann cell migration on sciatic nerve sections}

Sections of frozen sciatic nerve provide an in vitro substrate related to what Schwann cells encounter during their migration in vivo. In order to determine if Schwann cells use cell surface CD9 for their migration, we studied the effect of two anti-CD9 mAbs on Schwann cell migration on nerve substrates. Briefly, DRGs from neonatal day 1 rats were explanted onto normal adult sciatic nerve sections and cultured in RPMI/10\% FCS containing mAbs for $72 \mathrm{hr}$. Migrating Schwann cells were then visualized with a vital dye, carboxy fluorescein. We have previously demonstrated that the primary biological event in this bioassay is Schwann cell migration, not neurite extension or fibroblast migration (Anton et al., 1994a). Nearly all of the migrating cells in this assay ( $>95 \%)$ are Schwann cells, and neurite outgrowth is limited to $10-50 \mu \mathrm{m}$ around the DRG explant. In the presence of SMRA1 antibody, the average maximum distance of Schwann cell migration is $918 \pm 42 \mu \mathrm{m}(n=$ 12 ), whereas the migration in the absence of mAbs is $371 \pm 17$ $\mu \mathrm{m}(n=10)$ or in the presence of a control mAb, SMRA5, is $366 \pm 30 \mu \mathrm{m}(n=6)$ (Fig. $4 a-c)$. SMRA5 recognizes a Schwann cell surface antigen that remains to be identified. In addition to the SMRA5 control, a number of other mAbs that bind Schwann cell surfaces also do not affect migration (data not shown). Another anti-CD9 mAb, B2C11, also enhances migration to the extent of $848 \pm 109 \mu \mathrm{m}(n=10)$ (Fig. $4 d)$.

Since CD9 is expressed on PNS neurons as well as Schwann cells (Tole and Patterson, 1993), the effect of the SMRA1 on glial migration from the DRG explant could be due to an indirect effect, via the neurons. This, however, is unlikely because SMRA1 also promotes Schwann cell migration from sciatic nerve ex- 

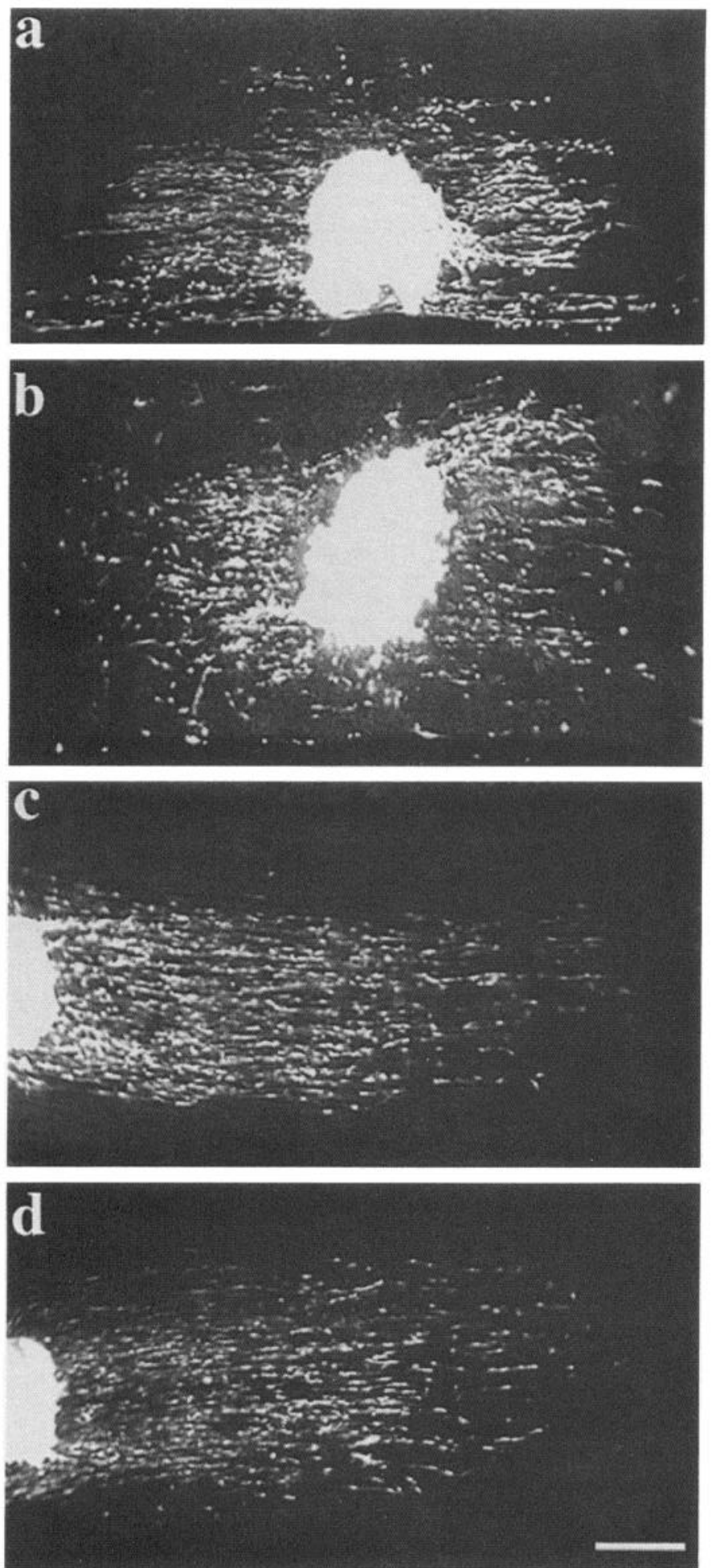

Figure 4. SMRA1 and B2C11 enhanced Schwann cell migration over adult sciatic nerve substrates. Schwann cells that migrate out of a DRG explant onto nerve substrates in the presence of RPMI $/ 10 \%$ FCS $(a)$, SMRA5 mAb $(b)$, SMRA $1 \mathrm{mAb}(c)$, and $\mathrm{B} 2 \mathrm{C} 11 \mathrm{mAb}(d)$ were visualized with carboxyfluorescein after $72 \mathrm{hr}$ in culture. Scale bar, $150 \mu \mathrm{m}$.

plants, which contain Schwann cells but no neurons [SMRA1, $875 \pm 42 \mu \mathrm{m}(n=9)$; no mAb, $411 \pm 41 \mu \mathrm{m}(n=7)]$. Moreover, pretreating the nerve substrate with SMRA1 and not including the $\mathrm{mAb}$ in the culture medium does not result in enhanced migration. Thus, it is likely that direct binding of anti-CD9
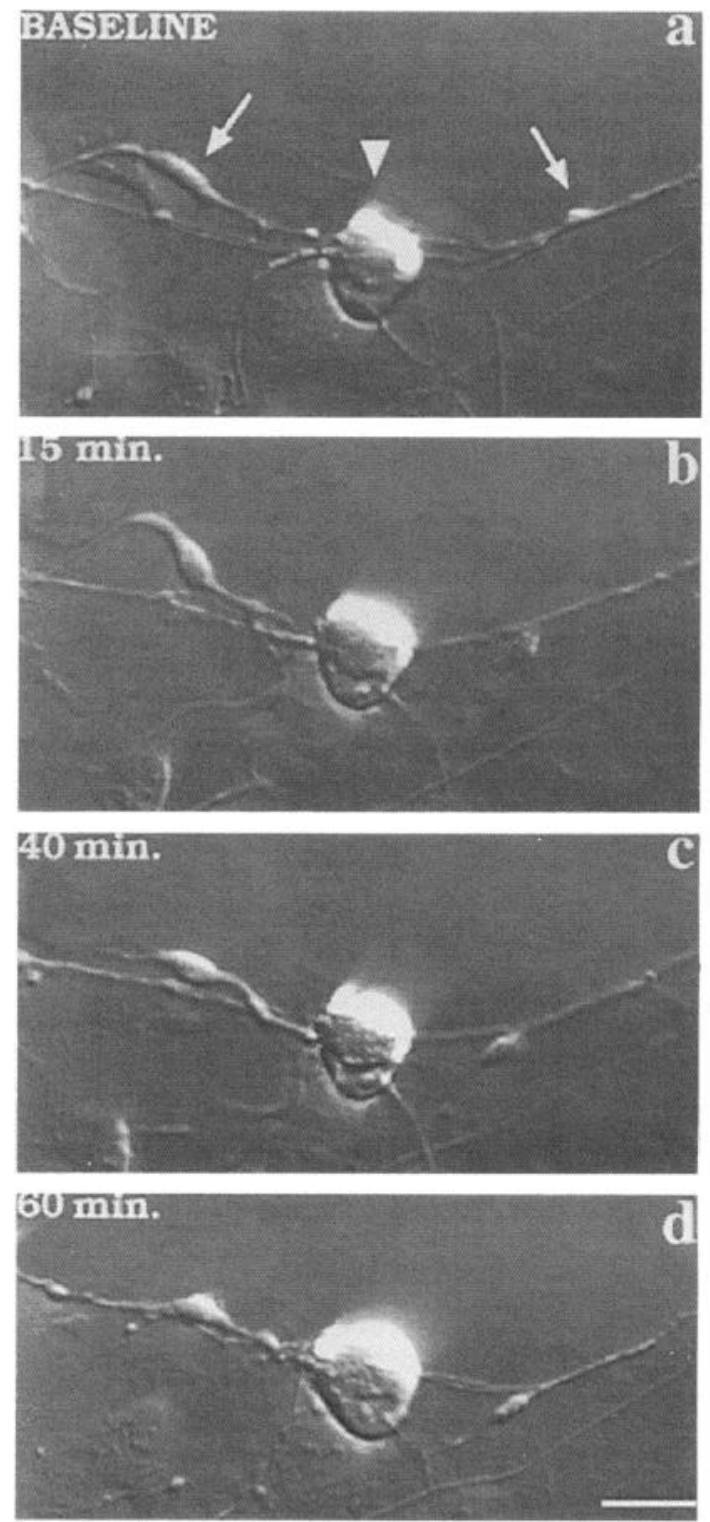

Figure 5. SMRA1 enhanced Schwann cell motility and adhesion on living neurites. Schwann cells (arrows) in contact with living axons were monitored prior to $(a)$ and after $(b-d)$ antibody perfusion. Schwann cells were barely motile prior to the addition of antibodies. After exposure to antibodies, Schwann cells adhere to and migrate on axons more rapidly. Arrowhead points to the neuron-Schwann cell clump from which the Schwann cells migrated out. Time (minutes) after antibody stimulation is noted in each panel. Scale bar, $35 \mu \mathrm{m}$.

mAbs to the migrating Schwann cell surface is essential for increased migration. The effect of SMRA1 on migration is more prominent on a normal adult sciatic nerve substrate than on a denervated sciatic nerve substrate. For example, on a normal nerve substrate, a $150 \%$ enhancement was seen in the presence of SMRA1 (when compared to the control mAb), whereas only a $79 \%$ enhancement was seen when denervated substrate is used instead.

\section{The SMRA1 antibody promotes Schwann cell migration on living axons}

The bioassay using nerve substrates mimics Schwann cell migration on extracellular matrix and basement membrane com- 

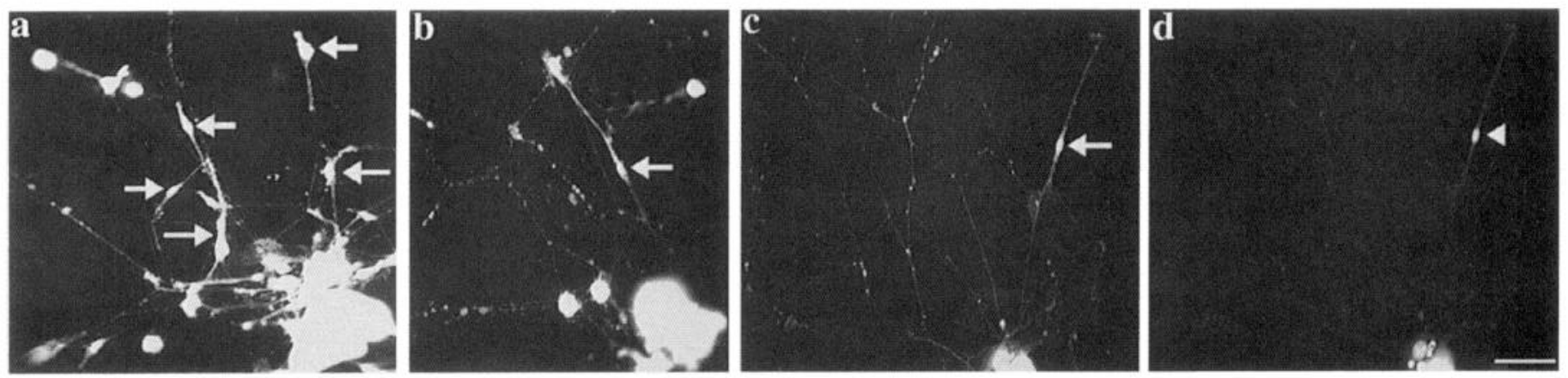

Figure 6. Increased number of Schwann cells adhere to living neurites in the presence of SMRA1. Number of Schwann cells (arrows) associated with living neurites were counted in the presence of SMRA1 mAb $(a)$, SMRA5 $(b)$, and RPMI $10 \%$ FCS $(c)$. Both axons and Schwann cells were labeled with carboxyfluorescein. Bis benzamide nuclei counterstain (arrowhead, $d$ ) and the bipolar, morphology of the cell in contact with the neurite $($ arrow,$c)$ indicate that it is a Schwann cell not a fibroblast or large neuritic varicosity. $d$ is the bis benzamide nuclear counterstain of $c$. Carboxyfluorescein labeled fibroblasts are identified by their flattened, round cell morphology and by the extensive membrane veil they display at their perimeter. Scale bar, $50 \mu \mathrm{m}$.

ponents. Schwann cells also migrate on axons, however. Therefore, we tested the ability of SMRA1 to influence Schwann cell migration on living axons. Precrushed, adult DRGs were dissociated into small neuron-Schwann cell clumps $(\sim 100 \mu \mathrm{m}$ in diameter) and cultured in RPMI $/ 10 \%$ FCS medium. Observation of cultures at various time points indicated that neurons in the clumps establish extensive neurite networks by $10-16 \mathrm{hr}$ in culture. Schwann cells in the neuron-Schwann cell clumps subsequently migrate along these neurites. Schwann cells are easily identified initially, because of their bipolar morphology and later, by S100 expression. After Schwann cells begin to migrate on neurites (approximately $24 \mathrm{hr}$ ), baseline Schwann cell morphology, migration rates, and attachment to neurites were monitored by video microscopy for $45 \mathrm{~min}$ prior to adding antibody to cultures. Exposure to SMRA1 enhances Schwann cell attachment to the neurites and increases their migration rates. Two typical Schwann cells are shown in Figure $5 a$ (arrows) in their basal state. The one on the left (Schwann cell 1) is attached to neurites on its bipolar ends whereas the one on the right (Schwann cell 2) randomly migrates on the axons at a rate of $\sim 8 \mu \mathrm{m} / \mathrm{hr}$. Beginning from about $15 \mathrm{~min}$ after SMRA1 perfusion, Schwann cell 1 moves downwards and eventually attaches strongly to the neurites (Fig. $5 b-d$ ). During and after this period of increased attachment, enhanced lamellapodial activity is seen in this Schwann cell. The migration rate of Schwann cell $\mathrm{b}$ increased to $\sim 30 \mu \mathrm{m} / \mathrm{hr}$ after mAb exposure as it moved back and forth along the main neurite and one of its small branches (Fig. $5 b-d)$. No such changes in morphology or migration rates are observed after perfusion of culture medium devoid of $\mathrm{mAbs}$ or containing control $\mathrm{mAbs}$ that bind to other antigens on Schwann cell surface. Efforts to reverse the effects of SMRA1 $\mathrm{mAb}$ by washing with $\mathrm{mAb}$-free medium did not yield any changes in $1 \mathrm{hr}$ after removal of mAbs.

In an effort to investigate if anti-CD9 mAbs cause enhanced affinity of Schwann cells to neurites, we added SMRA1 mAb to cultures at $24 \mathrm{hr}$ and evaluated the number of Schwann cells attached to neurites. An average of $4.3 \pm 0.34(n=34)$ Schwann cells associate with neurites in the presence of SMRA1, compared to $2.43 \pm 0.26(n=30)$ in the presence of control $\mathrm{mAb}$ SMRA5, or $2.31 \pm 0.24(n=38)$ in RPMI/10\% FCS medium (Fig. 6). It is likely that under control conditions most of the Schwann cells remained within the neuron-Schwann cell clump, instead of migrating out along the neurites.
It is apparent from these in vitro bioassays that the anti-CD9 mAbs bind to the CD9 molecule on the Schwann cell surface and influence its rate of migration and adhesion. To begin an investigation of second messenger pathways that may mediate these effects, we studied the effect of SMRA1 mAb on tyrosine phosphorylation and intracellular calcium.

\section{The SMRA1 mAb elicits a rise in internal calcium levels in Schwann cells}

Intracellular calcium levels before and after exposure to mAbs were monitored using a fluorescent calcium indicator, Fluo 3-AM. Images of Fluo 3-AM-loaded cells were recorded at one minute intervals using an SIT camera. After $15 \mathrm{~min}$ of baseline measurement, $\mathrm{mAbs}$ were perfused into the culture and changes in calcium levels recorded. Exposure to SMRA1 leads to a 63 $\pm 9 \%$ increase in Fluo 3-AM fluorescence, indicating a rise in internal calcium levels. This rise begins $12-15 \mathrm{~min}$ after the $\mathrm{mAbs}$ are pulsed in, and reaches its peak at about $35 \mathrm{~min}$. Elevated calcium levels remain stable for 2-3 $\mathrm{min}$, before returning to baseline levels by $50 \mathrm{~min}$ after stimulation (Fig. 7). In a majority of the experiments, Fluo 3-AM primarily labels Schwann cell bodies, and thus most of the calcium changes observed occurs in the cell soma (Fig. 7a). Occasionally, however, some of the bipolar processes are labeled, and in these cells, SMRA1-induced intracellular calcium increases in cell soma and processes precede morphological changes such as increased lamellapodial activity (Fig. 7a). For example, arrows on the Schwann cell images from 35 and 40 min poststimulation panels (Fig. 7a) indicate the lamellapodia or membrane protrusions induced by the antibody exposure. Changes in intracellular calcium preceded these morphological changes (Fig. 7a; 5-30 $\min$ ).

Measurement of calcium levels in Schwann cells bathed in culture medium devoid of mAbs indicates that calcium levels do not change randomly (Fig. 7 b). Similarly, exposure to a control Schwann cell surface molecule antibody, SMRA6, did not alter internal calcium levels (Fig. 7b).

\section{Changes in Schwann cell protein tyrosine phosphorylation induced by SMRA1 $\mathrm{mAb}$}

Changes in protein tyrosine phosphorylation were monitored at various time intervals after antibody stimulation by immunoblotting cell extracts with antibodies to phosphotyrosine. After 

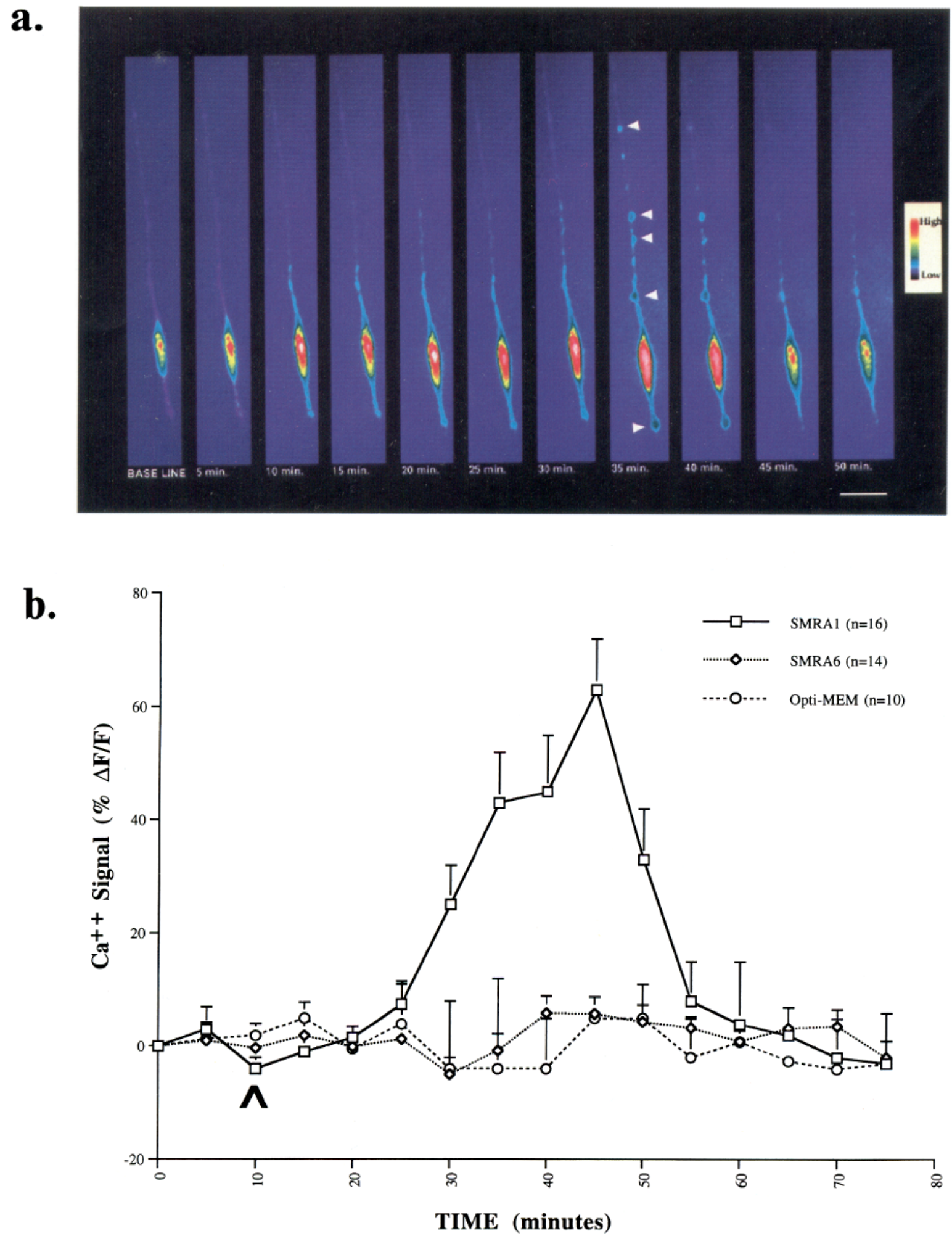

Figure 7. SMRAl evoked increase in intracellular calcium in Schwann cells. $a$, Pseudocolor images of Fluo 3-AM loaded Schwann cells were obtained prior to and after exposure to SMRA1 antibodies as described in Materials and Methods. Minutes after the exposure to antibodies is noted in the bottom of each panel. Higher fluorescent intensities, and thus higher calcium levels are coded as white followed by red. Blue indicates lower fluorescent intensities (white $>$ red $>$ blue). Arrowheads indicate lamellapodia or membrane protrusions induced by the $\mathrm{mAb}$. $b$, Changes in fluorescence $(\% \Delta F / F)$ in Schwann cells before and after exposure to SMRA1 $(n=16)$ or SMRA6 $(n=14)$ antibodies were quantified and plotted as a function of time. $\wedge$ indicates the time at which antibodies were perfused in. Changes in Schwann cells left unperturbed in opti-MEM medium $(n=10)$ were also illustrated. Only SMRA1 induced a rise in intracellular calcium level which eventually returned to baseline level. No changes were observed with either SMRA6 or opti-MEM medium. Scale bar in $A, 20 \mu \mathrm{m}$. 


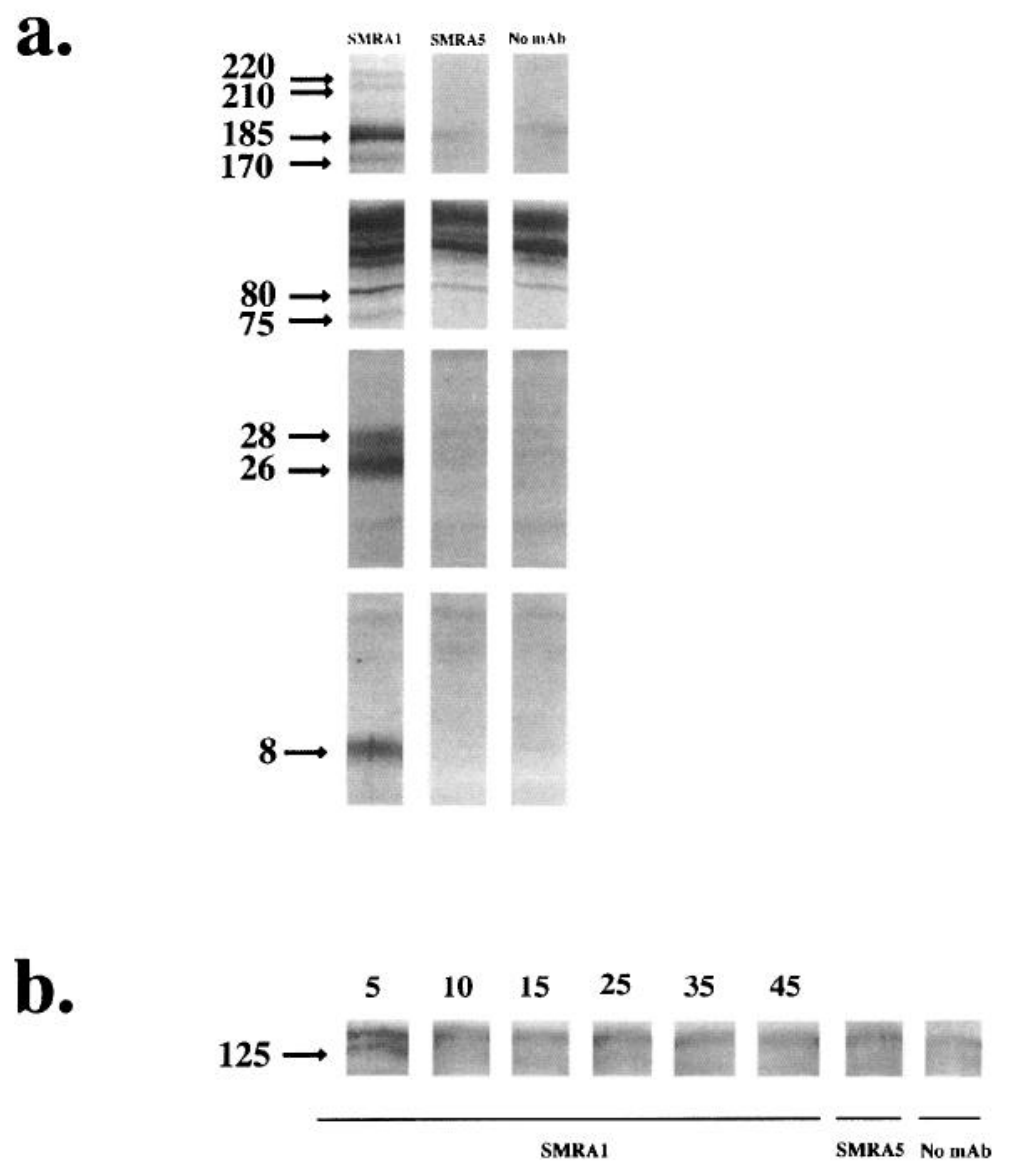

Figure 8. Changes in tyrosine phosphorylation of Schwann cell proteins in response to SMRA1 mAb exposure. $a$, Primary Schwann cells were incubated with SMRA1 mAb, SMRA5 mAb, or left unperturbed in RPMI $/ 10 \%$ FCS medium for $45 \mathrm{~min}$. Cells were then harvested and probed with anti-phosphotyrosine antibodies as described in Materials and Methods. Increased phosphorylation of several proteins were observed following exposure to SMRA1, but not to SMRA 5 or RPMI $10 \%$ FCS. Molecular weights of the proteins are noted at left in $\mathrm{kDa}$. $b$, a $125 \mathrm{kDa}$ protein was transiently phosphorylated 5 min after exposure to SMRA1. Neither SMRA5 nor RPMI $10 \%$ FCS affected the phosphorylation of this protein. Time interval after the exposure to antibodies is noted at the top of each lane.
$48 \mathrm{hr}$ in culture, primary Schwann cells were incubated with SMRA $1 \mathrm{mAb}$ for $5,10,15,25,35$, and $45 \mathrm{~min}$ before collecting the cells for analysis. Since primary Schwann cells exposed to the antibody begin to display morphological changes by $45 \mathrm{~min}$, we hypothesized that analysis at time intervals mentioned above should be sufficient to detect important tyrosine phosphorylation events induced by the mAb. Over this period, phosphorylation of proteins of $220,210,185,170,80,75,26,28$, and 8 $\mathrm{kDa}$ increased substantially relative to the amount of phosphorylation of those proteins in cells left untreated or treated with the control mAb, SMRA5 (Fig. 8a). Protein phosphorylation was also observed with $\mathrm{B} 2 \mathrm{C} 11$ by Hadjiargyrou and Patterson (personal communications). A $125 \mathrm{kDa}$ protein was transiently phosphorylated $5 \mathrm{~min}$ after stimulation with SMRA1; phosphorylation of this protein returned to basal levels within another $5 \mathrm{~min}$ (Fig. $8 b$ ). We did not detect any significant changes in dephosphorylation of proteins induced by SMRA1, even with the enhanced chemoluminescence (ECL) method.

\section{Discussion}

During the development and regeneration of peripheral nerves, migrating Schwann cells participate in interactions with other Schwann cells, with axons, and with extracellular matrix molecules that play a crucial role in axonal growth, guidance, and ensheathment. We have shown that mAbs against a cell surface, transmembrane $26 \mathrm{kDa}$ glycoprotein, CD9, regulate Schwann cell migration on living axons and on basement membrane/ extracellular matrix substrates. This regulation appears to involve changes in calcium levels and tyrosine phosphorylation.
In the preceding article Hadjiargyrou and Patterson (1994) demonstrate that immobilized, anti-CD9 mAbs modulate Schwann cell mitosis and adhesion. B2C11, the mAb that is mitotic in their experiments, is also a potent enhancer of Schwann cell migration in our assays. However, B2C11 produces its effect on migration at a concentration $(100 \mathrm{ng} / \mathrm{ml})$ well below its minimal mitotic dosage. Soluble SMRA1 mAb does not block or induce Schwann cell mitosis in cell proliferation assays (data not shown). Furthermore, ROCA2, a CD9 antibody without any demonstrable mitotic effect, also enhances migration in our assays. Thus, the enhanced migration we observe in our assays with CD9 antibodies is not an indirect result of increased Schwann cell mitosis. Nevertheless, CD9 could regulate both mitosis and migration of Schwann cells in vivo, where these two different Schwann cell behaviors are temporally separated. If the distribution of CD9 is also spatially separated, in terms of where it is expressed and the complexes it forms with other molecules, then it is not difficult to hypothesize that the temporal and spatial regulation of CD9 may modulate distinctly different behaviors (i.e., mitosis, migration, and myelination) in Schwann cells. CD9 is present in peripheral nerves during these different Schwann cell behaviors (Tole and Patterson, 1993; Kaprielian et al., 1994). Precisely how CD9 might be modified to function as a modulator of these varied behaviors remains unknown. Interestingly, the mitotic effect of CD9 antibodies requires that the mAbs be immobilized, whereas the effect of the mAbs on migration could be elicited by soluble mAbs, indicating that CD9 can modulate different behaviors in the same cell under different circumstances. 
A dynamic regulation of adhesion between Schwann cells, axons, and their surrounding matrix is likely to determine the migratory behavior of Schwann cells. Regulation of cell-substrate adhesion by CDY may well be a component in the enhanced migration induced by CD9 antibodies. The ability of CD9 mAbs to enhance Schwann cell migration on normal, adult sciatic nerve substrates that are generally not supportive of cell adhesion or growth (Sandrock and Matthew, 1987; Bedi et al., 1992; Anton and Matthew, unpublished observations), as well as the enhanced affinity between neurites and Schwann cells in the presence of the SMRAl mAb, support this hypothesis. In previous studies, mAbs to $\mathrm{CD} 9$ have been shown to increase homotypic and heterotypic cell-cell adhesion of platelets, pre-B cells, and endothelial cells (Jennings et al., 1990; Masellis-Smith et al., 1990; Forsyth, 1991). Moreover, overexpression of CD9 in various non-neural cell lines suppressed cell motility (Ikeyama et al., 1993). Taken together, these results strengthen the idea that $\mathrm{CD} 9$ is an important regulator of motility-related, adhesive events in the PNS.

What are the mechanisms whereby CD9 regulates Schwann cell migration? It is likely that the binding of SMRA1 to CD9 on the Schwann cell surface triggers a cascade of intraccllular events, resulting ultimately in changes in Schwann cell morphology and motility. SMRAl probably acts like the yet to be identified natural ligand of CD9. Alternately, SMRA1 might block an inhibitory function of CD9, thus allowing Schwann cells to respond in a positive fashion to its environmental cues. Studies done in platelets are instructive in deciphering the cascade of intracellular events that follows the activation of CD9. In platelets, $\mathrm{mAb}$ binding to $\mathrm{CD} 9$ elicits phosphatidyl inositol biphosphate $\left(\mathrm{PIP}_{2}\right.$ ) hydrolysis which eventually causes the release of calcium from internal storage organelles, activation of protein kinases, and increased cellular binding to cell adhesion molecules such as fibronectin (Seehafer and Shaw, 1991; Kroll et al., 1992; Yatomi et al., 1993). Similarly, mAbs to cell adhesion molecules LI and N-CAM are also thought to influence a similar set of second messengers in neural cells during regulation of neural cell adhesion (Schuch et al., 1989). In an effort to understand the signal transduction steps that connect the CD9-SMRA1 mAb binding to the morphological and motility changes in Schwann cells, we examined two signal transduction events associated often with changes in cell shape and motility: protein tyrosine phosphorylation and changes in calcium concentration.

In neurons, intracellular calcium mediates the transduction of environmental signals into motility and morphological responses by selectively influencing different components of the neuronal cytoskeleton (Forscher, 1989; Kater and Mills, 1991). In neural crest cells, changes in internal calcium levels influence both the degree of cell-cell adhesion and the onset of cell migration (Newgreen and Gooday, 1985; Doherty et al., 1991). We provide evidence that $\mathrm{CD} 9 \mathrm{mAb}$-induced changes in intracellular calcium influence neural crest-derived Schwann cells in an analogous manner. Using a calcium indicator, Fluo-3AM, which has been previously used to study intracellular $\mathrm{Ca}^{2+}$ changes in Schwann cells (Jahromi et al., 1992), we find that SMRA1 increases intracellular $\mathrm{Ca}^{2+}$ by $63 \pm 9 \%$ within $35 \mathrm{~min}$ of stimulation. This gradual rise in calcium over minutes is typical of studies where antibodies are used to modulate intracellular calcium (Schuch et al., 1989; Hato et al., 1990). The rise in internal calcium could be the result of activated ccll surface calcium channels or release of calcium from internal stores. In human platelets, both of these pathways are involved in the calcium rise induced by anti-CD9 antibodies (Favier et al., 1989). How does this internal calcium rise lead to enhanced cell motility in Schwann cells? Kater et al. (1988) hypothesized that there is an optimal level of intracellular calcium for cell motility and growth. It is possible that under the control conditions in our assays, Schwann cells migrate slowly, partly as a result of suboptimal levels of intracellular calcium. The SMRA1 $\mathrm{mAb}$ stimulation may raise the intracellular calcium concentration closer to the optimal level and thus stimulate cell migration.

Although it is evident that the SMRA1 mAb induces changes in intracellular second messenger systems, the interrelationship between these changes remains unclear. Since tyrosine phosphorylation changes were observed prior to $\left[\mathrm{Ca}^{2+}\right]_{i}$ changes were evident, it is conceivable that the latter is a downstream effect of tyrosine kinase activity. Conversely, calcium or some other second messenger such as 1,2-diacylglycerol that have been generated from $\mathrm{CD} 9$ activation could also activate various tyrosine kinases. What is clear, however, is that tyrosine phosphorylation of cellular components is an important element in the regulation of cell behavior (Ingraham and Mancss, 1990; Ullrich and Schlessinger, 1990; Schaller et al., 1993). In our studies, mAb SMRAl induces tyrosine phosphorylation of $220,210,185$, $170,80,75,26,28$, and $8 \mathrm{kDa}$ proteins. Another protein with molecular weight $125 \mathrm{kDa}$ was transiently phosphorylated. We have yet to characterize the tyrosine phosphorylated proteins beyond their molecular weights. However, several of these phosphorylated molecules could be important regulators of Schwann cell migratory behavior. For example, the $125 \mathrm{kDa}$ and $70 \mathrm{kDa}$ tyrosine phosphorylated proteins could be focal adhesion kinase $\mathrm{p} 125^{\mathrm{FAK}}$ and paxillin, respectively. Both are important focal adhesion-associated proteins that are thought to play crucial roles in cell adhesion, growth, shape, and motility (Burridge et al., 1992; Zachary and Rozengurt, 1992). The 160 $\mathrm{kDa}$ protein could be an $\alpha$-subunit of an integrin receptor, since the adhesive effect of CD9 has been shown to require an association with integrin receptors, and tyrosine phosphorylation of an integrin subunit could be a necessary step in this process (Slupsky et al., 1989). Tyrosine phosphorylation of integrins has also been proposed as a mechanism for the regulation of integrin-extracellular matrix affinity, a process important for cell motility (Hynes, 1992). Furthermore, mAb SMRA1 appears to induce a transformation in Schwann cells from a quiescent, relatively nonmotile state to an actively motile state. In Schwann cells, several proteins have been shown to regulate cell differentiation from one behavioral state to another. Examples of such proteins include, c-fos, c-src, SCIP, ras, N-myc, pCD25, and neu. (Ridley et al., 1988; Hengerer et al., 1990; Monuki et al., 1990; Nikitin et al., 1991; Pyykönen and Koistinaho, 1991; Sano et al., 1991; Spreyer et al., 1991). Of these, neu is of particular interest since it is a $185 \mathrm{kDa}$ receptor-like phosphoglycoprotein with tyrosine kinase activity that is thought to be a transducer molecule for Schwann cell proliferation controlling signals such as GGF (Lonardo et al., 1990; Nikitin et al., 1991; Marchionni et al., 1993). Perhaps CD9-induced phosphorylation of such a molecule may play an important role in a Schwann cell's decision to divide or migrate in response to CD9. Thus, it will be of interest to know if the $185 \mathrm{kDa}$ protein phosphorylated in our assays is neu.

Studics on molecules that define position in the nervous system have identified a putative epitope on $\mathrm{CD} 9$ as a molecular 
determinant of position in PNS (Suzuc ct al., 1990; Kapriclian and Patterson, 1993). The generation of positional identities in the nervous system is likely to involve cell movement and cell adhesion. These behaviors are also important elements in accurate and efficient regeneration of mammalian peripheral nerves (Brushart, 1990, 1993). The evidence provided here and by Hadjiargyrou and Patterson (1994) indicate that CD9 is involved in cell movement, adhesion, and mitosis. Such functional effects of CD9 on Schwann cells suggest that CD9 could well play a role both in the generation of rostrocaudal positional identity in the developing PNS and in accurate nerve regeneration following injury. This idea could be tested in in vivo pertubation studies using these CD9 mAbs. In utero surgery could be used to expose the early developing PNS to the anti-CD9 antibodies while the nerve entubulation model could be used to study the effects of mAbs on peripheral nerve regeneration (Williams ct al., 1983; Muneoka et al., 1990). Such in vivo experiments will help in confirming the role of CD9 as an important functional regulator of Schwann cell behavior in the PNS.

\section{References}

Acheson A, Barker PA, Alderson RF, Miller FD, Murphy RA (1991) Detection of brain-derived neurotrophic factor like activity in fibroblasts and Schwann cells: inhibition by antibodies to NGF. Neuron 7:265-275.

Akeson R, Warren SL (1984) Detection of a cell surface antigen found on rat peripheral nervous system neurons and multiple glia: astrocytes, oligodendrocytes, and Schwann cells. J Neurosci Res 12:4157.

Anderson PN, Turmaine M, Woodham P (1988) Schwann cells support extensive axonal growth into skeletal muscle implants in adult mouse brain. Neurosci Lett 93:127-131.

Anton ES, Weskamp G, Reichardt LF, Matthew WD (1994a) Nerve growth factor and low affinity NGF receptor promote Schwann cell migration. Proc Natl Acad Sci USA 91:2795-2799.

Anton ES, Sandrock AW, Matthew WD (1994b) Merosin promotes neurite growth and Schwann cell migration in vitro and nerve regeneration in vivo: evidence using an antibody to merosin, ARM-1. Dev Biol 164:133-146.

Ard MD, Bunge RP, Bunge MB (1987) Comparison of the Schwann cell surface and Schwann cell extra cellular matrix as promoters of neurite growth. J Neurocytol 16:539-555.

Bailey SB, Eichler ME, Villadiego A, Rich KM (1993) The influence of fibronectin and laminin during Schwann cell migration and peripheral nerve regeneration through silicone chambers. J Neurocytol 22:176-184.

Baron-Van Evercooren A, Kleinman HK, Seppä HEJ, Rentier B, Dubois-Dalcq ME (1982) Fibronectin promotes rat Schwann cell growth and motility. J Cell Biol 93:211-216.

Baron-Van Evercooren A, Gansmuller A, Duhamel E, Pascal F, Gumpel M (1992) Repair of a myelin lesion by Schwann cells transplanted in the adult mouse spinal cord. J Neuroimmunol 40:235-242.

Bedi KS, Winter J, Berry M, Cohen J (1991) Adult rat dorsal root ganglion neurons extend neurities on predegenerated but not on normal peripheral nerves in vitro. Eur J Neurosci 4:193-200.

Billings-Gagliardi S, Webster HF, O'Connell MF (1974) In vivo and electron microscopic observations on Schwann cells in developing tadpole nerve fibers. Am J Anat 141:375-392.

Blakemore WF (1976) Invasion of Schwann cells into the spinal cord of the rat following local injections of lysolecithin. Neuropathol Appl Neurobiol 2:21-39.

Blakemore WF, Franklin RJM (1991) Transplantation of glial cells into the CNS. Trends Neurosci 14:323-327.

Boucheix C, Benoit P (1988) CD9 antigen: will platelet physiology help to explain the function of a surface molecule during hematopoietic differentiation? Nouv Rev Fr Hematol 30:201-202.

Boucheix C, Soria C, Mirshahi M, Soria J, Perrot J-Y, Fournier N, Billard M, Rosenfeld C (1983) Characteristics of platelet aggregation induced by the monoclonal antibody ALB6 (acute lymphoblastic leu- kemia antigen p24); inhibition of aggregation by ALB6 Fab. FEBS Lett 161:289-295.

Boucheix C, Benoit P, Krief P, Billard M, Mishal Z, Azzarone B, Rendu E, Esnouf J, Bredoux R, Levy-Toledano S, Soria C, Perrot J-Y, Mirshahi M, Giannoni F, Bernadou A, Soria J (1987) Platelet aggregation induced by $\mathrm{CD} 9$ mAbs. Mechanisms and comparisons with platelet aggregating properties of mAbs directed against other membrane antigens. In: Leukocyte typing, Vol III, White cell differentiation antigens (McMichael AJ, ed), pp 780-792. New York: Oxford UP.

Boucheix C, Benoit P, Frachet P, Billard M, Worthington RE, Gagnon J, Uzan G (1991) Molecular cloning of the CD9 antigen: a new family of cell surface proteins. I Biol Chem 266:117-122.

Bradley WG, Jaros E (1979) Involvement of peripheral and central nerves in murine dystrophy. Ann NY Acad Sci 317:132-142.

Brockes JP, Fields KL, Raff MC (1979) Studies on cultured rat Schwann cells. I. Establishment of purified populations from cultures of peripheral nerve. Brain Res 165:105-118.

Brushart TM (1990) Preferential motor reinnervation: a sequential double labelling study. Restorative Neurol Neurosurgery 1:281-287.

Brushart TM (1993) Motor axons preferentially reinnervate motor pathways. J Neurosci 13:2730-2738.

Burridge K, Turner CE, Romer LH (1992) Tyrosine phosphorylation of paxillin and ppl $25^{\mathrm{FAK}}$ accompanies cell adhesion to extracellular matrix: a role in cytoskeletal assembly. J Cell Biol 119:893-903.

Cravioto U (1965) The role of Schwann cells in the development of human peripheral nerves. J Ultrastruct Res 12:634-651.

Curtis R, Stewart HJS, Hall SM, Wilkin GP, Mirsky R, Jessen KR (1992) GAP-43 is expressed by nonmyelin-forming Schwann cells of the peripheral nervous system. J Cell Biol 116:1455-1464.

Daniloff JK, Chuong CM, Levi G, Edelman GM (1986a) Differential distribution of cell adhesion molecules during histogenesis of the chick nervous system. J Neurosci 6:739-758.

Daniloff JK, Levi G, Grumet M, Rieger F, Edelman G (1986b) Altered expression of neuronal cell adhesion molecules induced by nerve injury and repair. J Cell Biol 103:929-945.

Daston MM, Ratner N (1991) Expression of P30, a protein with adhesive properties, in Schwann cells and neurons of the developing and regenerating peripheral nerve. J Cell Biol 112:1229-1239.

Engvall E, Earwicker D, Haaparanta T, Ruoslahti E, Sanes JR (1990) Distribution and isolation of four laminin variants; tissue restricted distribution of heterotrimers assembled from five different subunits. Cell Regul 1:731-40.

Favier R, Lecompte T, Morel MC, Potevin F, Benoit P, Boucheix C, Kaplan C, Samama M (1990) Calcium rise in human platelets elicited by anti-CD9 and- CD41 murine monoclonal antibodies. Thrombosis Res 55:591-599.

Fenely MR, Fawcett JW, Keynes RJ (1991) The role of Schwann cells in the regeneration of peripheral nerve axons through muscle basal lamina grafts. Exp Neurol 114:275-285.

Fields RD, Le Beau JM, Longo FM, Ellisman MH (1989) Nerve regeneration through artificial tubular implants. Prog Neurobiol 33: 87-134.

Forscher $\mathrm{P}$ (1989) Calcium and polyphosphoinositide control of cytoskeletal dynamics. Trends Neurosci 12:468-474.

Forsyth KD (1991) Anti-CD9 antibodies augment neutrophil adherence to endothelium. Immunology 72:292-296.

Franklin RJM, Blakemore WF (1993) Requirements for Schwann cell migration within CNS environments: a viewpoint. Int J Dev Neurosci 11:641-649.

Franz T (1990) Defective ensheathment of motoric nerves in the splotch mutant mouse. Acta Anat 138:246-253.

Goda S, Hammer J, Kobiler D, Quarles RH (1991) Expression of the myelin-associated glycoprotein in cultures of immortalized Schwann cells. J Neurochem 56:1354-1361:

Griffin JW, Drucker N, Gold BG, Rosenfeld J, Benzaquen M, Charnas LR, Fahnestock KE, Stocks EA (1987) Schwann cell proliferation and migration during paranodal demyelination. J Neurosci 7:682699.

Griffin L, Slupsky J, Seehafer J, Boshkov L, Shaw ARE (1991) Platelet activation by immobilized monoclonal antibody: evidence for a CD9 proximal signal. Blood 78:1753-1759.

Guernard V, Klietman N, Morrisey TK, Bunge RP, Aebischer P (1992) Syngenic Schwann cells derived from adult nerves seeded in semipermeable guidance channels enhance peripheral nerve regeneration. J Neurosci 12:3310-3320. 
Hadjiargyrou M, Patterson PH (1995) An anti-CD9 monoclonal antibody promotes adhesion and induces proliferation of Schwann cells in vitro. $\mathrm{J}$ Neurosci 15:574-583.

Hall DE, Reichardt LF, Crowley E, Holley B, Moezzi H (1990) The $a_{1} \beta_{1}$ and $a_{6} \beta_{1}$ integrin heterodimers mediate cell attachment to distinct sites on laminin. J Cell Biol 110:2175-2184.

Hall SM (1986a) Regeneration in cellular and acellular autografts in the peripheral nervous system. Neuropathol Appl Neurobiol 12:2746.

Hall SM (1986b) The effect of inhibiting Schwann cell mitosis on the reinnervation of acellular autografts in the peripheral nervous system of the mouse. Neuropathol Appl Neurobiol 12:401-414.

Hato T, Sumida M, Yasukawa M, Watanabe A, Okuda H, Kobayashi Y (1988) Induction of platelet $\mathrm{Ca}^{2+}$ influx and mobilization by a monoclonal antibody to CD9 antigen. Blood 5:1087-1091.

Hengerer B, Lindholm D, Heumann R, Rüther U, Wagner EF, Thoenen $\mathrm{H}$ (1990) Lesion-induced increase in nerve growth factor mRNA is mediated by c-fos. Proc Natl Acad Sci USA 87:3899-3903.

Heumann R, Lindholm D, Bandtlow C, Meyer M, Radeke MJ, Misko TP, Shooter ET, Thoenen H (1987) Differential regulation of mRNA encoding NGF and its receptor in rat sciatic nerve during development, degeneration, and regeneration: role of macrophages. Proc Natl Acad Sci USA 84:8735-8739.

Hynes RO (1992) Integrins: versatility, modulation, and signalling in cell adhesion. Cell 69:11-25.

Ikeyama S, Koyama M, Yamaoko M, Sassada R, Miyake M (1993) Suppression of cell motility and metastasis by transfection with human motility-related protein (MRP-1/CD9) DNA. J Exp Med 177: 1231-1237.

Ingraham CA, Maness PF (1990) Tyrosine phosphorylated proteins decrease during differentiation of neuronal and glial cells. Dev Neurosci 12:273-285.

Jaakkola S, Savunen O, Halme T, Uitto J, Peltonen J (1993) Basement membranes during development of human nerve: Schwann cells and perineurial cells display marked changes in their expression profiles for laminin subunits and $\beta 1$ and $\beta 4$ integrins. J Neurocytol 22:215230.

Jahromi BS, Robitaille R, Charlton MP (1992) Transmitter release increases intracellular calcium in perisynaptic Schwann cells in situ. Neuron 8:1069-1077.

Jennings LK, Fox CF, Kouns WC, McKay CP, Ballou LR, Schultz HE (1990) The activation of human platelets mediated by anti-human platelet p24/CD9 monoclonal antibodies. J Biol Chem 265:38153822.

Kanje M, Skottner A, Sjoberg J, Lundborg G (1989) IGF-1 stimulates regeneration of the rat sciatic nerve. Brain Res 486:396-398.

Kaprielian Z, Patterson PH (1993) Surface and cytoskeletal markers of rostrocaudal position in the mammalian nervous system. J Neurosci 13:2495-2508.

Kaprielian Z, Cho KO, Hadjiargyrou M, Patterson PH (1995) CD9, a major platelet cell surface glycoprotein, is a ROCA antigen and is expressed in the nervous system. J Neurosci 15:562-573.

Kater SB, Mills LR (1991) Regulation of growth cone behavior by calcium. J Neurosci 11:891-899.

Kater SB, Mattson M, Cohan CS, Connor J (1988) Calcium regulation of neuronal growth cone. Trends Neurosci 11:315-321.

Keynes REJ (1987) Schwann cells during neural development and regeneration: leaders or followers? Trends Neurosci 10:137-139.

Kioussi C, Crine P, Matsa R (1992) Endopeptidase-24.11 is suppressed in myelin-forming but not in non-myelin-forming Schwann cells during development of the rat sciatic nerve. Neuroscience 50:69-83.

Koistinaho J (1991) Nicotine-induced fos-like immunoreactivity in rat sympathetic ganglia and adrenal medulla. Neurosci Lett 128:4751.

Kroll MH, Mendelsohn ME, Miller JL, Ballen KK, Hrbolich JK, Schafer AI (1992) Monoclonal antibody AG-1 initiates platelet activation by a pathway dependent on glycoprotein IIb-IIa and extracellular calcium. Biochem Biophys Acta 1137:248-256.

Kromer LF, Cornbrooks CJ (1985) Transplants of Schwann cell cultures promote axonal regeneration in the mammalian brain. Proc Natl Acad Sci USA 82:6330-6334.

Le Beau JM, LaCorbiere M, Powell HC, Ellisman MH, Schubert D (1988) Extracellular fluid conditioned during peripheral nerve regeneration stimulates Schwann cell adhesion, migration and proliferation. Brain Res 459:93-104.
Lefcort F, Venstrom K, McDonald JA, Reichardt LF (1992) Regulation of expression of fibronectin and its receptor, alpha 5 beta 1, during development and regeneration of peripheral nerve. Development 116:767-782.

Letourneau PC, Roche FK, Shattuck TA, Lemmon V, Takeichi M (1991) Interaction of Schwann cells with neurites and with other Schwann cells involve calcium-dependent adhesion molecule, $\mathrm{N}$-cadherin. J Neurobiol 22:707-720.

Lonardo F, Di Marco E, King CR, Pierce JH, Segatto O, Aaronson SA, Di Fiore PP (1990) The normal erbB-2 product is an atypical receptor-like tyrosine kinase with constitutive activity in the absence of ligand. New Biol 2:992-1003.

Longo FM, Hayman EG, Davis GE, Ruoslahti E, Engvall E, Manthorpe $M$, Varon S (1984) Neurite-promoting factors and extracellular matrix components accumulating in vivo within nerve regeneration chambers. Brain Res 309:105-117.

Marchioni MA, Goodearl ADJ, Chen MS, Bermingham-McDonogh O, Kirk C, Hendricks M, Danehy F, Misumi D, Sudhalter J, Kobayashi K, Wroblewski D, Lynch C, Baldassare M, Hiles I, Davis JB, Hsuan JJ, Totty NF, Otsu M, McBurney RN, Waterfield MD, Stroobant P, Gwynne D (1993) Glial growth factors are alternatively spliced erbB2 ligands expressed in the nervous system. Nature 362:312-318.

Martin-Alonso JM, Hernando N, Ghosh S, Coca-Prados M (1992) Molecular cloning of the bovine CD9 antigen from ocular ciliary epithelial cells. J Biochem 112:63-67.

Masellis-Smith A, Jensen GS, Seehafer JG, Slupsky JR, Shaw ARE (1990) Anti-CD9 monoclonal antibodies induce homotypic adhesion of pre-B cell lines by a novel mechanism. J Immunol 144:1607-1613.

Matthew WD, Sandrock AW (1987) Cyclophosphamide treatment used to manipulate the immune response for the production of monoclonal antibodies. J Immunol Methods 100:73-82.

McCarthy JB, Palm SL, Furcht LT (1983) Migration by haptotaxis of a Schwann cell tumor line to the basement membrane glycoprotein laminin. J Cell Biol 97:772-777.

Meier R, Spreyer P, Ortmann R, Harel A, Monard D (1989) Induction of glia-derived nexin after lesion of peripheral nerve. Nature 342 $548-550$

Montero-Menei CN, Pouplard-Barthelaix A, Gumpel M, Baron-Van Evercooren A (1992) Pure Schwann cell suspension grafts promote regeneration of the lesioned septo-hippocampal cholinergic pathway. Brain Res 570:198-208.

Monuki ES, Kuhn R, Weinmaster G, Trapp BD, Lemke G (1989) Expression and activity of the POU (ranscription factor SCIP. Science 249:1300-1303.

Morrissey TK, Kleitman N, Bunge R (1991) Isolation and functional characterization of Schwann cells derived from adult peripheral nerve. J Neurosci 11:2433-2442.

Muneoka K, Wanek N, Trevino C, Bryant SV (1990) Exo utero surgery. In: Post-implantation mammalian embryo (Coops A, Cockroft D, eds), pp 41-59. Oxford: IRL.

Neuberger TI, Cornbrooks CI, Kromer LF (1992) Effects of delayed transplantation of cultured Schwann cells on axonal regeneration from central nervous system cholinergic neurons. J Comp Neurol 315:1633.

Nicke J, Schachner M (1985) Expression of neural cell adhesion molecules L1 and N-CAM and their common carbohydrate epitope L2/ HNK-1 during development and after transection of the mouse sciatic nerve. Differentiation 30:141-151.

Nikitin AY, Ballering LAP, Lyons J, Rajewsky MF (1991) Early mutation of the neu (erbB-2) gene during ethylnitrosourea induced oncogenesis in the rat Schwann cell lineage. Proc Natl Acad Sci USA 88:9939-9943.

Noakes PG, Bennett MR (1987) Growth of axons into developing muscles of the chick forelimb is preceded by cells that stain with Schwann cell antibodies. J Comp Neurol 259:330-347.

Noakes PG, Bennett MR, Davey DF (1983) Growth of segmental nerves into the developing rat diaphragm: absence of pioneer axons. J Comp Neurol 218:365-377.

Noakes PG, Bennett MR, Stratford J (1988) Migration of Schwann cells and axons into developing forelimb muscles following removal of either the neural tube or the neural crest. J Comp Neurol 277:214233.

Perkins CS, Bray GM, Aguayo AJ (1981) Ongoing block of Schwann cell differentiation and deployment in dystrophic mouse spinal roots. Dev Brain Res 1:213-220. 
Peters A, Muir AR (1959) The relationship between axons and Schwann cells during development of peripheral nerves in the rat. J Exp Physiol 44:117-130.

Pyykönen I, Koistinaho J (1991) C-fos protein like immunoreactivity in non-neuronal cells of rat peripheral nerve after transection. Acta Neuropathol (Berl) 82:66-71.

Ramon y Cajal S (1924) Degeneration and regeneration of the nervous system. London: Hafner.

Ridely AJ, Paterson HF, Noble M, Land H (1988) ras-mediated cell cycle arrest is altered by nuclear oncogenes to induce Schwann cell transformation. EMBO J 7:1635-1645.

Sandrock AW, Matthew WD (1987) Substrate-bound NGF promotes neurite growth in peripheral nerve. Brain Res 425:360-363.

Sanes JR, Engvall E, Butkowski R, Hunter DD (1990) Molecular heterogeneity of basal laminae: isoforms of laminin and collagen IV at the neuromuscular junction and elsewhere. J Cell Biol 111:168599.

Sano K, Motoike T, Nakamura H, Matsui Y, Teranishi Y, Takai Y (1991) Differential expression of the N-myc, c-fos, and smg p25A genes in human neuroblastoma cells during neuronal and Schwannian differentiation. Mol Brain Res 9:149-152.

Schaller MD, Bouton AH, Flynn DC, Parsons JT (1993) Identification and characterization of novel substrates for protein tyrosine kinases. Prog Nucleic Acid Res Mol Biol 44:205-224.

Schuch U, Lohse MJ, Schachner M (1989) Neural cell adhesion molecules influence second messenger systems. Neuron 3:13-20.

Seehafer JG, Shaw ARE (1991) Evidence that the signal-initiating membrane protein CD9 is associated with small GTP-binding proteins. Biochem Biophys Res Commun 179:401-406.

Siironen J, Sandberg M, Vuorinen V, Röyattä M (1992) Laminin BI and collagen type IV gene expression in transected peripheral nerve: reinnervation compared to denervation. J Neurochem 59:2184-2192.

Slupsky JR, Seehafer JG, Tang SC, Masellis-Smith A, Shaw ARE (1989) Evidence that monoclonal antibodies against $\mathrm{CD} 9$ antigen induce specific association between CD9 and the platelet glycoprotein IIbIIIa complex. J Biol Chem 264:12289-12293.

Spreyer P, Kuhn G, Hanemann CO, Gillen C, Schaal H, Kuhn R, Lemke
G, Müller HW (1991) Axon-regulated expression of a Schwann cell transcript that is homologous to a 'growth arrest-specific' gene. EMBO J 10:3661-3668.

Suzue T, Kaprielian Z, Patterson PH (1990) A monoclonal antibody that defines rostrocaudal gradients in the mammalian nervous system. Neuron 5:421-431.

Taniuchi M, Clark HB, Schweitzer JB, Johnson EM (1988) Expression of NGFr by Schwann cells of axotomized peripheral nerves: ultrastructural location, suppression by axonal contact, and binding properties. J Neurosci 8:664-681.

Tole S, Patterson PH (1993) Distribution of CD9 in the developing and mature rat nervous system. Dev Dynamics 197:94-106.

Toma JG, Pareek S, Barker P, Mathew TC, Murphy RA, Acheson A Miller FD (1992) Spatiotemporal increases in epidermal growth factor receptors following peripheral nerve injury. J Neurosci 12 : 2504-2515.

Ullrich A, Schlessinger J (1990) Signal transduction by receptors with tyrosine kinase activity. Cell 61:203-212.

Williams LR, Longo FM, Powell HC, Lundborg G, Varon S (1983) Spatial-temporal progress of peripheral nerve within a silicone chamber: parameters for a bioassay. J Comp Neurol 218:460-470.

Yamamoto M, Sobue G, Li M, Arakawa Y, Mitsuma T, Kimata K (1993) Nerve growth factor (NGF), brain-derived neurotrophic factor (BDNF), and low affinity nerve growth factor receptor (LNGFR) mRNA levels in cultured rat Schwann cells; differential time- and dose-dependent regulation by cAMP. Neurosci Lett 152:37-40.

Yatomi Y, Ozaki Y, Satoh KK, Kume S (1993) Anti-CD9 monoclonal antibody elictis staurosporine inhibitable phosphotidylinostol 4,5biphosphate hydrolysis, phosphatidylinositol 3,4-biphosphate synthesis, and protein-tyrosine phosphorylation in human platelets. FEBS J 322:285-290.

Zachary I, Rozengurt E (1992) Focal adhesion kinase (p125 ${ }^{\mathrm{FAK}}$ ): a point of convergence in the action of neuropeptides, integrins, and oncogenes. Cell 71:891-894.

Ziskind-Conhaim L (1988) Physiological and morphological changes in developing peripheral nerves of the rat embryos. Dev Brain Res $42: 15-28$. 